\title{
From Dispute to Decision: Suing Polluters in China*
}

\author{
Rachel E. Stern ${ }^{\dagger}$
}

\begin{abstract}
This article traces a civil environmental lawsuit from dispute to decision to explore how environmental law works, as well as how lawyers and litigants try to work the law. Detailing ground-level encounters with a legal system promoted and carefully watched by political elites offers a fresh perspective on the ways the past 30 years of legal reforms have affected the experience of China's court users. Amid accounts of financial stress, lawyer-client tensions and the hunt for elite allies, what emerges is a story of variation. Although plaintiffs and lawyers agree that environmental cases are hard and wringing concessions out of polluters requires remarkable persistence, the process sometimes creaks forward so that appraisals are conducted on time, help is solicited and compensation won. How Chinese courts work (and how well they work) depends on local circumstances, an insight that suggests that disaggregating expansive concepts like rule of law is a helpful way to explore complexity instead of glossing over it.
\end{abstract}

In Pingnan County 屏南县, the epicentre of what Legal Daily and the All-China Lawyers' Association would later name one of 2005's ten most influential lawsuits, the Rongping joint chemical plant (Rongping lianyinghua gongchang, 容 屏联营华工厂), was initially welcomed as a source of tax revenue and over 300 new jobs. In 1992, when the factory opened, Pingnan was located in one of the poorest parts of Fujian province, a place where local sayings ("Pingnan, Pingnan is poor and hard") verged on lamentations. Over the next ten years, however, crops started dying and health problems spread. When petitions and media reports failed to address complaints, 1,721 villagers filed a class action lawsuit against the factory in 2002. Three years and one appeal later, the Fujian Provincial High People's Court ordered Rongping to pay 684,178.2 yuan (US $\$ 100,614)$ in compensation and clean up industrial waste. This translates to

* This article is based on research funded by a Fulbright-Hays Doctoral Dissertation Research Abroad Grant, a Doctoral Dissertation Improvement Grant from the National Science Foundation, the UC Berkeley Institute for International Studies and the UC Berkeley Center for Chinese Studies. Many thanks to Jenny Chio, Rongbin Han, Jonathan Hassid, Robert Kagan, Kevin J. O’Brien, Stephanie Stern, Leslie Wang and Xiaohong Yu for helpful comments on earlier drafts. Please note that this article does not necessarily reflect the views of the National Science Foundation.

$\dagger$ Society of Fellows, Harvard University. Email: restern@fas.harvard.edu 
roughly 397 yuan per plaintiff (US\$58), an ambiguous victory for what many observers saw as a landmark environmental case. ${ }^{1}$

The Pingnan story intersects familiar themes for those attentive to the news coming out of China in the late 2000s: China's severe environmental problems and overarching turn towards courts and law. Yet despite a surge of research interest in both topics, ${ }^{2}$ little apart from newspaper articles has been written about environmental litigation. Stepping behind the headlines, this article traces a civil environmental lawsuit ${ }^{3}$ from dispute to decision to explore how environmental law works (including processes and institutions) as well as how lawyers and litigants try to work the law (including obstacles and strategies). This account of a journey through the courts draws primarily on 14 months of fieldwork from November 2006 to January 2008 and over 130 interviews with Chinese plaintiffs, lawyers, judges and others familiar with environmental litigation. The cases recounted below are not meant to be representative, but rather illustrative of the problems encountered and solutions attempted.

Of course, there are many ways to resolve disputes without recourse to courts. In focusing on how litigation works, the point is not that lawsuits are the most common - or even the best - way to address environmental problems. The vast majority of environmental disputes are handled through government-brokered deals, private concessions or simply when plaintiffs give up and go away. ${ }^{4}$ But such disputes are rising. There were 616,122 environmental complaints nationwide in 2006, a 60 per cent increase over 2001, 5 and the Vice-Minister of Justice commented in 2007 that "mass cases coming from conflicts over ... environmental

1 For more about the Pingnan case in English, see Alex Wang, "The role of law in environmental protection in China: recent developments," Vermont Journal of Environmental Law, Vol. 8 (2007), especially pp. 212-19; and Shai Oster and Mei Fong, "In booming China, a doctor battles a polluting factory," The Wall Street Journal, 19 July 2006. All conversions are calculated at the January 2010 exchange rate of 6.8 yuan per US\$.

2 For examples of recent work on Chinese law, see Kevin J. O'Brien and Lianjiang Li, "Suing the local state: administrative litigation in rural China," The China Journal, No. 51 (2004), pp. 75-96; Neil J. Diamant, Stanley Lubman and Kevin J. O'Brien (eds.), Engaging the Law in China (Stanford, CA: Stanford University Press, 2005); Ethan Michelson, "The practice of law as an obstacle to justice: Chinese lawyers at work," Law \& Society Review, Vol. 40, No. 1 (2006), pp. 1-38; Mary Gallagher "Mobilizing the law in China: 'informed disenchantment' and the development of legal consciousness," Law \& Society Review, Vol. 40, No. 4 (2006), pp. 783-816; Ethan Michelson, "Lawyers, political embeddedness and institutional continuity in China's transition from socialism," American Journal of Sociology, Vol. 113, No. 2 (2007), pp. 352-414. For examples of recent work on environmental issues, see Guobin Yang, "Environmental NGOs and institutional dynamics in China," The China Quarterly, No. 191 (2005), pp. 44-66; Ralph Litzenger, "In search of the grassroots: hydroelectric politics in northwest Yunnan," in Elizabeth J. Perry and Merle Goldman (eds.), Grassroots Political Reform in Contemporary China (Cambridge, MA: Harvard University Press, 2007), pp. 282-99; Andrew C. Mertha, Water Warriors: Citizen Action and Policy Change (Ithaca, NY: Cornell University Press, 2008).

3 For a companion piece on administrative environmental litigation, see Xuehua Zhang, "Enforcing environmental regulations in Hubei province, China: agencies, courts citizens," PhD dissertation, Stanford University, 2008.

4 The All China Environment Federation, a government-backed non-governmental organization, estimates that no more than $1 \%$ of environmental disputes reach the courts. See Jing Li, "Group wants more polluters in court," China Daily, 16 January 2008.

5 Zhongguo huanjing nianjian (China Environment Yearbook) (Beijing: China Environment Press), 2001, p. 681 , and 2007, p. 727. 
policies are growing by the day."6 And while the government does not release annual statistics on civil environmental lawsuits, a 2008 Xinhua news article reported 4,453 pollution compensation cases in 2004, followed by 1,545 cases in 2005 and 2,146 in 2006. ${ }^{7}$ Although these are not huge numbers, several thousand cases a year demonstrate that litigation is a standard (if relatively infrequent) way to handle environmental disputes. ${ }^{8}$

Equally important, low frequency events can illuminate social dynamics as well as high frequency ones. As a growing literature on courts in illiberal states recognizes, litigation in tightly controlled political systems is often not just an extension of state authority, but a hard-fought struggle that makes visible daily conflicts over class, citizenship and power. ${ }^{9}$ Focusing on just one process of dispute resolution and one type of dispute brings these tensions into high relief. Rather than reaching for pronouncements about the rule of law writ large, detailing ground-level encounters with courts promoted and carefully watched by political elites reveals a more textured view of legalization. Quotidian chronicles of financial stress, lawyer-client tensions or the hunt for elite allies reveal much about the ways in which the post-Mao push to write new laws, professionalize the judiciary and strengthen the courts has (and has not) trickled down to China's court users.

\section{Getting a Case into Court}

In environmental disputes, getting a day in court is more often a hard-won privilege than a basic entitlement. Under the Environmental Protection Law, would-be plaintiffs have three years from when they became aware of pollutionrelated losses to file a claim, one year longer than the typical statute of limitations for tort cases. Sometimes, as in the Pingnan case, the court counts time spent seeking administrative solutions against the statute of limitations, a real problem when bureaucracies move slowly or fail to act altogether. The right to sue, a legal concept known as standing, is also limited to those who have directly suffered harm. ${ }^{10}$ Only pollution victims (wuran shouhaizhe 污染受害者), not

6 Quoted in Human Rights Watch, Walking on Thin Ice: Control, Intimidation and Harassment of Lawyers in China (New York: Human Rights Watch, 2008), pp. 28-29.

7 Xinhua News Agency, "Lü Zhongmei daibiao: jianyi sheli huanjing shenpanting" ("Representative Zhongmei Lü suggests establishing an environmental bench"), 8 March 2008, available at http:/l tinyurl.com/ya5u749. With only three years of data (and no idea how cases were collected or counted), trends regarding the total number of civil environmental lawsuits are unclear, especially as a judge at the Supreme People's Court told me in September 2007 that pollution cases were rising 25\% per year (2007-84).

8 By way of comparison, federal American courts issued opinions in an average of 110 civil environmental cases a year from 1992 to 2002. See James R. May, "Now more than ever: trends in environmental citizen suits at 30," Widener Law Review Vol. 10, No. 1 (2003), p. 8.

9 See, in particular, Tamir Moustafa, The Struggle for Constitutional Power: Law, Politics and Economic Development in Egypt (Cambridge: Cambridge University Press, 2007), p. 3.

10 In the late $2000 \mathrm{~s}$, several local courts - including new environmental courts and court divisions - began experimenting with expanding standing in environmental cases to include the procuratorate, and the All China Environment Federation. 
environmental activists or sympathetic lawyers, can bring a case and even they are not guaranteed a court hearing. Judges at the court's filing division (li'an ting 立案庭), the first stop in bringing a lawsuit, routinely refuse cases. Although case refusal is supposed to be accompanied by a written rationale, judges often skip this step, leaving plaintiffs without the record of refusal necessary to formally appeal the decision. Judges say they turn away cases for a variety of reasons, such as because an administrative solution is under way or because law is not an appropriate way to solve the problem (2007-55). ${ }^{11}$ In practice, of course, these decisions give judges latitude to sidestep volatile disagreements that might affect social stability or annual court evaluations. Day to day, this means the filing division often has the unenviable task of persuading very angry people to seek redress elsewhere. In so doing, judges sometimes exercise individual discretion and sometimes follow orders, such as when ad hoc confidential regulations instruct courts to refuse certain types of cases or handle them in a certain way. ${ }^{12}$

The difficulty of manoeuvring cases past the filing division is well known ${ }^{13}$ and, for many would-be plaintiffs, the primary emotion associated with law is frustration. In a futile five-month quest to get an environmental dispute accepted by the courts, one Hunan man took ten trips to the basic level court, three trips to the intermediate court and two trips to the high court. Here is a typical entry from the journal he kept:

[18 October 2004] Three days later, I went to the intermediate court to tell them about the situation and hand over my written documents ... throwing the materials I had written aside, assistant division head Ding said: "Go to the basic level court! Don't come back looking for us!" Swallowing my anger, I picked up the documents from the floor and put them back on the counter. I wanted to go to the central court offices to find the court leaders, but the gatekeeper wouldn't let me in. ${ }^{14}$

The commonness of exclusion leaves some environmental lawyers ready to declare success as soon as a case is accepted (2007-91). After all, without a hearing, "there's no place to even talk" (2007-14).

The filing division also has the discretion to break up collective lawsuits. China is one of the few countries besides the United States to allow lawsuits on behalf of a large group of people with the same grievance. Under the 1991 Civil Procedure Law, citizens can bring collective lawsuits led by two to five representatives, a logical course of action when pollution affects an entire neighbourhood or village. ${ }^{15}$ Often, however, courts divide collective lawsuits into individual cases in

11 For a list of personal communication citations, see the Appendix.

12 A recurrent rumour during my fieldwork involved a Supreme People's Court memo ordering lower courts to refuse major environmental cases (2006-13; 2006-19; 2007-19).

13 Basic level courts also frequently turn away disputes that have previously been through administrative mediation (xingzheng tiaojie) although there is no legal basis for this. See Sida Liu, "The logic of fragmentation: an ecological analysis of the Chinese legal services market," $\mathrm{PhD}$ dissertation, University of Chicago, 2009, p. 75 and O'Brien and Li, "Suing the local state," pp. 80-82.

14 Document on file with the author.

15 For more on group litigation, see Benjamin L. Liebman, "Class action in China," Harvard Law Review (1997-1998), pp. 1523-41. 
order to maximize per case court fees, boost statistics on the number of cases handled or disarm collective action. But filing paperwork for hundreds (or even dozens) of identical cases is a burden (2007-87; 2007-96; 2007-98). Photocopying documents and lugging around boxes is enough of a deterrent that lawyers say even persuading a court to treat each family as a unit instead of individuals is a minor accomplishment (2007-98).

Many local observers interpret trouble getting on the docket as an outgrowth of local protectionism (difang baohu 地方保护). This is by far the most frequently cited explanation for most litigant difficulties, and refers to the widespread conception that the local government shelters large polluters who prop up the local economy. ${ }^{16}$ The Pingnan case is a particularly good example of how focusing on economic growth can create a situation where, as one Environmental Protection Bureau (EPB) employee put it, "if there wasn't a factory, there wouldn't be a government" (2007-68). By 2003, tax revenues from Rongping chemical plant comprised more than 25 per cent of the county's 20 million yuan (US\$2.9 million) annual budget. ${ }^{17}$ While local protectionism is not always a factor, powerful political protectors can certainly sway courts dependent on local government for salaries, benefits, housing and facilities.

Lawyers' fluency in the language of the law and personal connections make them a natural asset in initially beating back local protectionism by drawing up legal briefs, submitting preliminary evidence and talking a case into the courts. ${ }^{18}$ The trouble for many complainants lies in finding a lawyer willing to take the case. ${ }^{19}$ Yet contrary to the common view of poverty-stricken pollution victims, some would-be plaintiffs can scrape together the money for a competitive attorney fee (2007-42). Nongmin 农民, the Chinese administrative designation for anyone involved in agricultural work, covers a range of incomes, including those more akin to farm bosses than farmhands. In 2007, I observed a 90-minute contract negotiation between a group of nongmin and two environmental lawyers which centred on the relative wealth of the villagers (as one lawyer said, "I've seen people much poorer than you!"). The two sides settled on a 60,000 yuan (US\$8,823) fee paid in instalments, a decent amount of money considering that a reasonably successful mid-career Beijing lawyer might net about 20,000 yuan per month and that per capita rural income was 4,140 yuan per year

16 For more on local protectionism in environmental enforcement, see Benjamin van Rooij, Regulating Land and Pollution in China: Lawmaking, Compliance, and Enforcement; Theories and Cases (Leiden: Leiden University Press, 2005), especially pp. 191-209; and Xuehua Zhang, "Enforcing environmental regulations in Hubei province," especially pp. 51-53. Work on local state corporatism also details how county and township governments collude with rural enterprises to achieve economic growth targets. For more, see Jean Oi, Rural China Takes Off: Institutional Foundations of Economic Reform (Berkeley: University of California Press, 1999).

17 Xinwen diaocha (News Probe), "Pingxicun pang de huagongchang" ("The chemical plant next to Pingxi village"), 12 April 2003, transcript available at http://tinyurl.com/yecgebo.

18 Plaintiffs are allowed to represent themselves in a civil lawsuit and it is an open question how often lawsuits move forward without legal representation.

19 For more on how Chinese lawyers screen cases, see Michelson, "The practice of law as an obstacle to justice." 
in 2007.20 While the group may have had hidden sources of income (possibly remittances or past profits from bumper harvests), it is equally likely that they decided that scrimping for a lawyer was worth it.

Still, even when clients can offer a market-rate fee, many lawyers remain wary of environmental cases because of the potential political sensitivity and the amount of legwork involved. Collective lawsuits are particularly troublesome because plaintiffs must individually opt in, which typically means that the legal team must submit a copy of each litigant's identity card (shenfenzheng 身份证) to the court. ${ }^{21}$ And even those willing to track down dozens (or hundreds) of identity cards sometimes balk at situations in which the polluter enjoys strong local government support. These lawyers delicately inquire about the extent of local protectionism during preliminary interviews or simply refuse cases where the polluter is a major taxpayer. Physical danger is also a concern (2007-18; 2007-112). One Beijing lawyer, for example, is afraid that the mafia investors behind polluting enterprises will beat him up on investigatory trips to isolated factories (2007-81).

Coaxing a lawyer into taking a case is often easier with law firms registered outside the immediate area. ${ }^{22}$ Neither polluters nor their local government supporters usually have the high-level connections necessary to cause trouble for non-local lawyers (2006-10; 2007-86; 2007-96; 2007-106). Lawyers' daily conduct and, more importantly, annual licence renewal are overseen by the local justice bureau and it is not easy to orchestrate bureaucratic pressure from far away. As a criminal lawyer in Zhejiang explains it: "Local lawyers won't accept the case, but go to lawyers in other places, maybe more famous, so they will not offend local leaders. I often go to other counties to handle cases." ${ }^{23}$ Bringing in famous lawyers, particularly from big cities like Beijing and Shanghai, disposes judges to take complaints more seriously too. In a well-known administrative lawsuit against the Beijing urban planning bureau, for example, plaintiffs credited their success to the national reputation of the lead lawyer. ${ }^{24}$ Sometimes, local and non-local lawyers team up to unite outsiders' prestige and relative freedom with insiders' local connections and on-the-ground ability to collect evidence and file paperwork (2007-96).

But signing up plaintiffs and assembling a legal team is no guarantee that either side will see a case through. When harassment picks up, even committed lawyers reconsider their priorities. One Hebei lawyer, for example, dropped an

20 Wen Jiabao, 2008 Guowuyuan zhengfu gongzuo baogao (2008 State Council Government Work Report), available at http://tinyurl.com/ygwfzbv.

21 Litigants must individually opt in to a lawsuit and providing a copy of an identity card is one way to indicate support. In the US, in contrast, civil actions cover an entire class of people (e.g. those who bought a certain brand of laptop between 2000 and 2002). While individuals in the class must be notified of pending litigation and can opt out, they do not need to opt in individually.

22 See Fürst, "Access to justice," pp. 90-91 for an example of a case that was turned down by local lawyers before plaintiffs found legal representation in Beijing.

23 Quoted in Liu, "The logic of fragmentation", p. 222.

24 Wendra Liang, "From protesters to plaintiffs: pollution lawsuits and the tradition of protest in the People's Republic of China,” MA dissertation, Stanford University, 2006, p. 64. 
environmental case after the suddenly overzealous local water bureau - probably under pressure from well-connected polluters - intensified inspections at his law firm (2008-2). Disappearing plaintiffs are also common. Several lawyers I interviewed spent a significant time investigating cases and collecting evidence only to find complainants unwilling to sue (2007-34; 2007-71; 2007-106). The fact that collective lawsuits require official representatives makes it particularly easy to identify, cajole and discourage leaders. In a 2002 collective case in Beijing, a construction company offered two representatives 50,000 yuan (US\$7,352) each to relocate and drop the lawsuit. ${ }^{25}$ Plaintiffs in other cases report widespread intimidation, such as local officials entering homes, eating food and using the bathroom without invitation. ${ }^{26}$ In addition to bribes and threats, inertia also saps energy during a long lawsuit. Maintaining hope, especially in collective lawsuits, requires both persistence and talented leadership. The Pingnan case was successful in large part because the village unified around the head representative, a middle-aged man named Zhang Changjian 张长建 who ran the local medical clinic. Dubbed the lawsuit's “emotional leader” (jingshen lingxiu 精神领袖) by the press, Zhang told a reporter in 2004 that "I can't move. Right now, everyone is watching me. If I retreat, everyone will disband."27

Front-loaded case acceptance fees (anjian shouli fei 案件受理费) also force even the angriest plaintiffs to calculate the monetary value of court-brokered justice. Although the State Council lowered litigation fees in 2007 to make it easier to bring civil claims, acceptance fees can be high enough to compel consideration. Court fees for cases involving less than 10,000 yuan (US\$1,470) in requested compensation are cheap - a flat 50 yuan - but above 10,000 yuan, fees are calculated as a decreasing, sliding percentage of the amount requested. This ranges from 0.5 per cent of requested compensation (over 200 million yuan requested) to 2.5 per cent (between 10,000 and 1 million yuan requested). If losses are significant and litigation fees high, poor plaintiffs' best recourse is to obtain proof of poverty and petition the court to waive fees or delay payment. ${ }^{28}$ Often, these decisions rely on a judge's assessment as to whether applicants are troublemakers (diaomin J民) or the deserving poor. Poor courts reliant on litigation fees are also less likely to approve fee waivers than richer courts with diverse sources of income (2007-55).

In the initial struggle to get a case accepted by the courts, lawyers and litigants also face a strategic decision: where to sue. For civil cases, there are three levels of courts of first instance (basic level courts, intermediate courts and high courts)

27 Haining He, "Yige xiao shancun de huanbao jianxin lu" ("One mountain village's difficult road towards environmental protection," Nanfang zhoumou (Southern Weekend), 16 September 2004, available at http://tinyurl.com/6d15mvq.

28 Proof of poverty can come from the local Party committee, the neighbourhood committee, the civil affairs department of the local government or the local labour bureau and is accepted at the court's discretion. 
with one appeal possible. Important cases (zhongda anjian 重大案件), defined in the Civil Procedure Law as those "with a significant impact within the particular jurisdiction," bypass the basic court and go straight to the intermediate or high court. The definition of an "important case" varies by province, but also often involves a baseline level of compensation. Although it is relatively unusual, starting with the intermediate court and appealing to a higher court if necessary is seen as one way to lessen the obligation that accompanies basic level courts' budgetary reliance on local government and, by extension, major taxpayers. Higher-level courts are better insulated from local pressure, staffed by bettereducated judges and more likely to return favourable decisions (2006-3; 2006-15). ${ }^{29}$ Sometimes, this works. In a 2002 water pollution case in Tangshan 唐山, for instance, the high court admonished the intermediate court for a grave legal error (yanzhong falü cuowu 严重法律错误) and sent the case back on remand. ${ }^{30}$ Yet skipping levels is increasingly difficult. A 2005 Supreme People's Court notice effectively limited most environmental cases to lower courts by mandating that all collective lawsuits start in basic level courts. ${ }^{31}$ And on the rare occasions when non-mass cases involve sufficient losses to qualify as "important," individual plaintiffs may have to lower their requested compensation to afford case acceptance fees.

Another choice is to work horizontally to find a court somewhat insulated from the polluter's political influence. When pollution crosses borders, several different courts are likely to have jurisdiction and filing a case as far away from the source of pollution as possible usually makes sense (2007-99). ${ }^{32}$ In particular, China's maritime courts may be particularly good places to bring water pollution lawsuits (2007-9; 2007-65). Like intellectual property tribunals, maritime courts handle a high number of cases involving foreign companies, and centrally appointed judges have a reputation for being professional and relatively well-educated. In a landmark 2002 case, for example, the Tianjin maritime court held several Hebei paper companies liable even though emissions met national standards. The plaintiffs' Beijing-based legal team ascribed success to their choice of court, later writing that using maritime courts can "remove the administrative interference that accompanies local protectionism, bring the advantage of specialized courts and expert judges into play, increase the efficiency of the case and guarantee justice." 33 Today, one of the lawyers involved in the case believes that the Tianjin maritime court is the best place to bring water pollution cases in the country.

29 See also O'Brien and Li, "Suing the local state," pp. 85-86.

30 The intermediate court re-decided in favour of the plaintiffs. Hebei High Court (2004), Liu Honggui et al. v. Tangshan jiaohuachang youxian zeren gongsi, decision on file with the author.

31 Supreme People's Court, "Notice regarding problems with the acceptance of class action lawsuits by the People's Courts,” effective 1 January 2006.

32 See also Kathinka Fürst, "Access to justice in environmental disputes: opportunities and obstacles for Chinese pollution victims," MA dissertation, University of Oslo, 2008, pp. 95-96.

33 Document on file with the author. 


\section{Inside the Court}

Legally, civil environmental cases hinge on two key legal points. First, the Environmental Protection Law and the revised 2009 Tort Liability Law agree that polluters are liable for damages even if discharge meets government standards. Second, the revised 2009 Tort Liability Law, the 2008 Water Pollution Law, the 2004 Solid Waste law and a 2001 Supreme People's Court explanation (jieshi 解释) shift the burden of proof such that defendants are responsible for proving that pollution did not cause losses. This latter point is particularly important for pollution victims looking for compensation. Environmental cases turn on causation and it is notoriously difficult to prove (or deny) a connection between pollution and harm. Still, even strong evidence of causation does not guarantee that plaintiffs will receive the full amount of requested compensation. Judges often split the blame for losses, a legal concept known as shared liability. In a 2004 case in Shandong, for example, two fish farmers only received 51 per cent of their requested compensation on the grounds that they should have sought government help mitigating the effects of an oil spill. ${ }^{34}$

Once inside the court, the first step is to demonstrate that pollution exists. One common form of evidence is amateur photographs and videos of devastated landscapes or toxic-looking runoff. The gold standard, however, is government reports, which are seen as "very authoritative" (feichang quanwei 非常权威) (2007-20) and "comprehensive" (quanmian 全面) (2007-91). ${ }^{35}$ Some lawyers even find major cases easier to litigate because of the increased likelihood of government reports documenting pollution (2007-21). The most obvious source of information is the local EPB, an agency whose competence and objectivity varies. In some places, lawyers find that the EPB efficiently conducts tests on request without demanding fees (2007-57). Elsewhere, however, it is less responsive. When Zhang Changiian started lodging complaints in Pingnan, for example, the closest EPB with pollution monitoring equipment was three hours away, making impromptu inspections nearly impossible. ${ }^{36}$ In places with uncooperative EPBs, court users sometimes learn to work around the agency. One repeat plaintiff in Hebei now requests help from the relatively sympathetic agricultural bureau instead (2007-107).

When they exist, there is also no guarantee that pollution data will be accurate or accessible. In some places, long stretches of county-mandated "enterprise quiet days" (qiye anjing $r i$ 企业安静日) disallow environmental inspections on the grounds that it would interrupt production. ${ }^{37}$ Factories are also adept at hiding

34 Zhang Pengguo and Li Yuping v. Shengli youtian gongyi xinjishu shiyou kaifa youxian zeren gongsi, Shandong Dongyang Intermediate Court, Civil Division No. 27 (2004).

35 For more on the importance of government reports, see Joseph McMullin, "Do Chinese environmental laws work? A study of litigation as response to fishery pollution," UCLA Pacific Basin Law Journal, No. 26 (2009).

36 News Probe, "The chemical plant next to Pingxi village."

37 See Xuehua Zhang, "Enforcing environmental regulations in Hubei province," p. 51. In two of the counties Zhang studied in Hubei, enterprise quiet days lasted from the 1st to the 25th of each month. 
pollution even from assiduous inspectors. Tricks include polluting only at night, building secret underground discharge pipes and storing wastewater in pools that flood during rainstorms. And when government agencies do manage to document pollution, the resulting reports are often tightly guarded. Although judges are officially responsible for investigating the unclear aspects of a case, soliciting evidence frequently requires wheedling reports out of bureaucrats with little incentive to co-operate. One conscientious Tianjin judge made three trips to the EPB to obtain pollution data, succeeding only after he went drinking with local officials (2007-74). In the Pingnan case, the plaintiffs' lawyers could pry documents out of the EPB only when they knew enough to request them by name (2007-15). Yet despite the difficulty of tracking down government data, independent scientific analysis is relatively rare. Outside expertise is expensive and, litigants fear, too easily dismissed as biased (2006-15). In politically sensitive cases, it can also be hard to find labs willing to run tests. In Shanxi, one lawyer was unable to get water samples analysed because environmental monitoring stations denied owning the necessary equipment. ${ }^{38}$

While courts can track the history of pollution through routine government reports, day-to-day environmental monitoring does not typically touch on causation or damages. Across legal systems, pollution-related compensation claims hinge on the tricky business of proving quantifiable economic losses linked to pollution. This is hard because damages, like dead fish, could be caused by other factors besides pollution, like overfeeding or overcrowding. Although the burden of proof rests with the defendant to prove that pollution did not cause damages, local courts routinely rule against plaintiffs because of doubts about causation. Cases involving lots of small enterprises are especially challenging because individual responsibility is so difficult to untangle (2007-87). Small companies are also more likely to be unregistered, so tracking down an owner to sue can be a problem (2007-99). To bypass the morass of causation, one strategy is to rely on a clear-cut standard. A case in Tangshan, Hebei, for example, hinged on whether the factory violated a 1986 regulation requiring a 1,000 metre buffer zone between industry and a residential neighbourhood (2007-21).

In the absence of clear-cut standards, judges typically rely heavily on outside appraisals, usually conducted by either a government bureau or a courtappointed appraisal agency. ${ }^{39}$ Depending on the scope of the appraisal, the resulting report might assess damages, come to a conclusion about causation or both. Judges often lack the time or skills to investigate environmental cases and, in theory, a scientifically informed assessment helps improve the quality and efficiency of decisions. In fact, cases often hang on appraisals, as judicial decisions rarely deviate far from a report the court regards as unbiased.

38 Linling Xu, "Susong zhi wang: Yan Yiming" ("The king of litigation: Yan Yiming"), Nanfang zhoumou (Southern Weekend), 9 May 2009.

39 For more on how judges make decisions, see Rachel E. Stern, "On the frontlines: making decisions in Chinese civil environmental lawsuits," Law \& Policy, Vol. 32, No. 1 (2010), pp. 79-103. 
Yet even the most expert appraisals are more akin to a good guess than scientific proof. Many of the effects of pollution, like a tree's stunted growth, are difficult to quantify, especially when there is no consensus on the best way to calculate damages. In the absence of a set standard, court decisions spend long paragraphs discussing, for example, whether dead fish should be valued at the wholesale or retail price. ${ }^{40}$

During my fieldwork, observers agreed that appraisals were both essential to the success of a case and of greatly uneven quality (2007-85; 2007-91). The local justice bureau is responsible for licensing both appraisal organizations (jianding jigou 鉴定机构) and individual appraisers, but the qualifications for the job are relatively flexible. For example, appraisers can get a licence with just five years of relevant work experience and a related undergraduate major. ${ }^{41}$ Clued-in judges know that an appraisal licence does not necessarily indicate competence and deeper evaluation is necessary. After several phone calls, one judge passed up a prestigious Qinghua University-affiliated organization because employees lacked the necessary skills (2007-74). Often, cases move ahead with a less-than-capable organization responsible for the key piece of evidence. In an environmental hearing I observed in Hebei in 2008, the appraisal team did not include a single plant expert even though their primary task was evaluating damage to a fruit orchard. Or, in the Pingnan case, plaintiffs complained that the court-appointed appraiser spent less than a day in the village and only did a brief visual assessment of a small piece of forest located quite far from the factory. ${ }^{42}$ Often, lawyers suspect that experts were pressured or bought off rather than merely incompetent. In a case in Inner Mongolia, an appraisal was written and stamped the same day inspections took place and before test results were available. ${ }^{43}$

Despite the fact that hired experts are often seen as biased, litigants sometimes commission their own appraisal, picking an organization based on personal ties, efficiency, technical competence and location (2007-91; 2007-111). Some lawyers say that picking a northern-based appraiser for a case in the south (and vice versa) enhances objectivity (2007-91). One issue with this strategy is that independent experts are expensive. Although the cost of an appraisal depends on the amount of work involved and who is hired to do it, it often falls in the 10,000 to 50,000 yuan (US\$1,470-7,352) range, no small amount for plaintiffs typically already suffering economic losses. Nor is documentation necessarily a first

40 Guangdong Foshan Intermediate Court (2005), Ping Zao v. Zhongnan Shiyouju, Civil Division No. 3 , decision on file with the author.

41 Appraisers must have five years of relevant work experience and one of the following: a high-level technical title, equivalent professional qualifications, or a related undergraduate or graduate major. See Ministry of Justice, "Sifa jiandingren dengji guanli banfa" ("Regulations governing the registration of appraisers"), effective 30 September 2005.

42 "Pingnanxian qianyu cunmin suanbao songan shimo" ("The whole story of an environmental lawsuit involving over 1,000 villagers from Pingnan county"), Caijing, 15 July 2006, available at http:/l tinyurl.com/yzj9qdb.

43 Fürst, "Access to justice in environmental disputes," p. 53. 
impulse after pollution. Dead fish or rotting crops are often cleared away before would-be plaintiffs ever consider litigation (2007-27).

During the actual hearing, lawyers' best rhetorical opportunity is the closing statement (known in civil cases as the dailici 代理词). Lawyers see this as an opportunity to lay out an argument that flawlessly demonstrates their legal logic and education (2007-91; 2007-97). The clearest sign of success is when court decisions echo lawyers' legal arguments, as they occasionally do (2007-91). For the more theatrically inclined, closing statements also provide a dramatic chance to appeal to judges' empathy, ego and patriotism. Playing on the government's historical sympathy for economic distress, lawyers often cast their clients as members of a weak and disadvantaged group (ruoshi qunti 弱势群体). ${ }^{44}$ For example, a Beijing lawyer opened a 2003 closing statement:

My client is a middle-aged laid-off worker who is the backbone of a family with two children in middle school and a grandmother over 80 years old ... he borrowed 30,000 yuan [US\$4,411] from the bank, friends and relatives, and signed a contract to raise fish in Lake X ... he took this much risk and bore the hopes of his entire family! Imagine, a person of this age without a high school education or specialized skills. As soon as fish farming fails, he not only has no opportunity to get back the money but may drag three generations into his difficulties. ${ }^{45}$

When it arises, environmentalism is primarily couched as "rightful resistance" and framed "in reference to protections implied by ideologies or conferred by policymakers." ${ }^{66}$ One lawyer sees environmental slogans as "points of support" (zhichengdian 支承点) to buttress statements like "how can a harmonious society exist when everything is polluted?" (2007-106). Others neatly interweave environmentalism and patriotism, as in this excerpt from the closing statement in the Pingnan case:

I am a Beijing lawyer and university professor. The reason I'm paying attention to an environmental case thousands of kilometres away is not because I'm going to get any benefit from the case. Rather, it is because I see piece after piece of my country's green mountains turned desolate and bare by corrupt profiteers and section after section of clear river turned into a dirty gutter ... As a Chinese person who has not lost his reason, I cannot help using the law to help protect environmental rights and to protect our weak and disadvantaged groups who rely on the homeland to live.

After reminding the judges of his status ("I am a Beijing lawyer and university professor"), the lawyer evokes Chinese pride in support of environmental rights. Reasonable Chinese people, he implies, should protect the homeland from destruction.

In these final remarks, lawyers sometimes urge judges to uphold justice and even make history. One lawyer defending an environmental protester told the court that "those who should be judged are neither the defendants whose

44 Weak and disadvantaged groups are usually defined as including the handicapped, women, juveniles, the elderly, the poor, and laid-off, unemployed and migrant workers. For more on official tolerance for moral economy claims, see Elizabeth Perry, "Challenging the mandate of heaven: popular protest in modern China," Critical Asian Studies, Vol. 33, No. 2 (2001), p. 168.

45 All closing statements are on file with the author.

46 Kevin J. O’Brien and Lianjiang Li, Rightful Resistance in Rural China (Cambridge: Cambridge University Press, 2006), p. 3. 
human rights and property rights were violated nor those weak and disadvantaged groups living at the bottom rungs of society, but those at the chemical companies responsible for [this] ... pollution accident! ... They will stand accused by history." Strategically overlooking the possibility of political pressure or downright corruption, this aspirational view of the court calls on judges to live up to the best traditions of Chinese justice.

\section{Outside the Court}

Many plaintiffs understand that judicial decisions can depend as much on what happens outside the court as within it. In the search for sympathetic elite allies willing "to enter the implicit or explicit bargaining arena" on their behalf, they typically both exhaust their net of personal connections and petition strangers. ${ }^{47}$ Among a range of potential backers, however, litigants and lawyers often share a common impulse to turn first to the media. Those familiar with the Chinese legal system know that media exposure often catalyses concessions. ${ }^{48}$ Local governments may not be afraid of lawsuits, but they are afraid of the spotlight. As one lawyer put it, "if the media didn't exist, public interest litigation wouldn't be possible" because external scrutiny heightens accountability and, in so doing, brings a degree of power to those who lack it (2007-14). In China, as elsewhere, complaints easily go unheard unless "perceived and projected." ${ }^{49}$ Media reports, often submitted as evidence or mentioned in lawyers' closing statements, remind judges of a wider audience and broader social responsibility. At the same time, sympathetic coverage lends litigants a measure of protection by informing opponents that they are being watched (2007-50).

Not all types of media attention are the same, however. Although litigants and lawyers eagerly court domestic coverage, most are more reluctant to talk to the international media. While foreign attention can intensify pressure and bring results, it can also give complaints an unwanted radical cast (2006-10; 2007-18; 2007-53; 2007-75). At the very least, caution is called for. One well-known lawyer advised complainants not to take money from international reporters or pass on government documents because those actions could later be interpreted as leaking state secrets (2007-100). Within China, local media outlets are not allowed to report on events above their administrative level and, in addition, are often barred by the local propaganda department from covering stories regarding locally powerful polluters (2007-15; 2007-18; 2007-21; 2007-82; 2007-109). In contrast, the national media are generally free to report any story that does not implicate officials above the county level $(2007-40$; 2007-75) and are more likely to provide in-depth coverage of environmental disputes. (At the provincial

47 Michael Lipsky, "Protest as a political resource," The American Political Science Review, Vol. 62 (1968), pp. 1144-58. See also O'Brien and Li, "Suing the local state," pp. 86-89.

48 Benjamin L. Liebman, "Watchdog or demagogue? The media in the Chinese legal system," Columbia Law Review, Vol. 105, No. 1 (2005), p. 111.

49 Lipsky, "Protest as a political resource," p. 1151. 
level and above, environmental reporters say it is best "not to touch a tiger" (2007-75).) In the Pingnan case, plaintiffs found that "the central media were our best allies" (2007-39). The day after a particularly influential news segment aired on China Central Television's News Probe (Xinwen diaocha), for example, the EPB sent out an inspection team (2007-39).

Ad hoc alliances between journalists and litigants reflect the broader rise of the green media and advocacy journalism..$^{50}$ The late 1990s and early 2000s saw the emergence of self-identified environmental journalists at mainstream newspapers like China Youth Daily (Zhongguo qingnian bao 中国青年报) and Legal Daily (Fazhi ribao 法制日报). Encouraged by a monthly environmental journalists' salon started by Green Earth Volunteers in 2001, some journalists began selfconsciously using the press to call attention to pollution. Their efforts fit into a larger tradition of Chinese advocacy journalism, characterized by frequent use of the first person and a distinct moral position. Even outside the op-ed page, these reports clearly take sides, usually with the powerless. The influential 2003 News Probe television segment on the Pingnan case, to take one example, interweaves advocacy journalism with investigative reporting, a common combination. The reporter, dressed in glasses and a business suit, is cast as a big city intellectual fighting rural injustice. In standard Mandarin (roughly the class and educational equivalent of Oxford English), he contrasts the plant's emphatic denials of illegal pollution with shots of worn villagers and barren countryside. As the Chinese media are now largely reliant on advertising rather than government subsidies, popular appeal is increasingly important and this kind of story makes good television, replete with villains, underdogs and heroes (2007-38).

Of course, soliciting media coverage is not easy. When litigants and journalists do not share a social circle, contacting the media is challenging. Letters and emails are likely to go unanswered and travelling to news bureaus in major cities is time-consuming and expensive. Nor do even sympathetic journalists necessarily see the newsworthiness of yet another pollution story. Media savvy lawyers brainstorm fresh angles before calling press contacts (2007-82) or simply don't bother pitching run-of-the-mill cases (2007-69). And recruiting a reporter is only the first step. Journalists can be bought off or stories killed by editors under pressure (2007-38; 2007-40). Subtler local evasion, like intransigence from polluters, can also limit the depth and impact of reports. In Hebei, for example, one court released the decision just before Spring Festival to deter media attention (2007-115). In addition, media backlash is a real danger. Irritation with headlinechasing self-appointed heroes can undercut public support as well as engender it. Rather than face accusations of "making a big deal out of nothing" (xinwen chaozuo 新闻炒作), some lawyers avoid the media altogether (2007-94). Others

50 The term "advocacy journalism" is borrowed from Jonathan H. Hassid, "Four models of the fourth estate: a typology of contemporary Chinese journalists," The China Quarterly, forthcoming. Also see Lili Wang, Lu meiti (Green Media) (Beijing: Qinghua University Press, 2005). 
say "the internet is the best choice for poor people" because, unlike reporters, the web never demands money in exchange for coverage (2009-5).

Another part of mobilizing personal networks is taking advantage of connections inside the state. Political embeddedness, such as ongoing formal and informal ties to bureaucrats, can ease the work of case preparation and protect lawyers from harassment. ${ }^{51}$ Contacts can help with specific favours, like access to environmental reports, and serve as character references. One Beijing lawyer, for example, asks friends in government to spread the word that he is a "good guy" when he is working on a sensitive case (2007-66). Lawyers also use personal ties to talk a case into the courts $(2007-77 ; 2007-111)$ or convince judges of their point of view $(2007-23 ; 2007-75 ; 2007-79)$. Cases can turn on the opportunities provided by personal access, and those who know the right people - often because of social class or education - benefit. Yet networking, although common, is not the only way to find allies. Sympathetic insiders occasionally slip key evidence to lawyers or litigants because their conscience demands it (2007-32). As one official told a Kunming lawyer, "working for the government is temporary, but you are a person for your whole lifetime" (2007-102).

Even as litigants tally contacts and weigh strategies, most struggle with a far more basic problem: maintaining unity. In the months and years leading up to a mass lawsuit, plaintiffs often disagree over both their understanding of the problem and the best solution. The residents of one Sichuan village, for example, were paralysed by competing explanations for high cancer rates including farm chemicals, anger and anxiety, and diet, smoking and drinking. ${ }^{52}$ Without a consensus about who to blame, resignation and apathy dominated anger and action. Commitment can also dissipate over the course of a lawsuit, rupturing once solid coalitions. The spatial dynamics of pollution, in particular, generate tensions between plaintiffs unequally affected by the problem. A compensation offer viewed as reasonable by villagers a fair distance from a factory, for example, can be seen as entirely unreasonable by those closer by. ${ }^{53}$ In mixed income communities, class also affects plaintiffs' ability to escape pollution. In an air pollution case in Hebei, richer residents moved, leaving their poorer neighbours to sue on their own (2007-21). For all of these reasons, it is sometimes easier for lawyers to work with stable associations than ad hoc collections of complainants. A fisherman's association, say, or a homeowner's association typically has leaders in place and existing relationships with government bureaus, both significant advantages in litigation (2007-73).

Staying unified is a problem not only for plaintiffs but also for the broader legal team. Lawyers and clients, as elsewhere, are separated by a gulf of

51 The term "political embeddedness" is borrowed from Michelson, "Lawyers, political embeddedness and institutional continuity," p. 356.

52 Anna Lora-Wainwright, "Of farming chemicals and cancer deaths: the politics of health in contemporary rural China," Social Anthropology, Vol. 17, No. 1 (2009), p. 63.

53 Fürst, "Access to justice in environmental disputes," p. 83. 2007-8 and 2007-46 also discussed how proximity to pollution motivates activism. 
"knowledge, assurance and social standing" and the resulting relationship can be tense. ${ }^{54}$ Lawyers complain that plaintiffs are uneducated, grasping and "blind" (mangmu 盲目) to the law (2007-18; 2007-21; 2007-34; 2007-91; 2007-102; 2007-109). Lack of legal knowledge, they say, leads to unrealistic demands and frustration if compensation is not quickly forthcoming (2007-18; 2007-78; 2007-109). The support litigants often demand can be especially irritating. High maintenance clients call frequently to check on the status of their case, report new developments or, in one case, just to talk about family problems (2007-91; 2007-18; 2007-21). My conversation with a Zhejiang lawyer in November 2007 was interrupted by the unexpected arrival of three villagers who had travelled an hour and a half to follow up on the previous day's phone call. The displeased lawyer (possibly also embarrassed in front of a guest) told them their behaviour was "unbelievably irritating" (fansile 烦死了) and to go away and stop wasting his time. "Sometimes," he later confided, "I just can't help getting angry" (2007-102).

This is all to say that deep power inequalities underlie lawyer-client relationships. Most commonly, clients quietly comply with lawyers' instructions. As one plaintiff described his relationship with his lawyers, "they told me what to do and I did it" (2007-39; see also 2007-22; 2007-41). While some lawyers are tightly integrated into local communities, legal authority can also shade into neglect or casual condescension as differences in social standing sharpen. In March 2007, I observed a group of Beijing lawyers ask a villager who had travelled for over 24 hours for legal advice to leave the room while they drew up a strategy for his case. Even more telling, we were several minutes into lunch after the meeting before someone noticed that the client wasn't there. "Maybe he got arrested on the way over here," a lawyer joked as he left the restaurant to look for him. ${ }^{55}$ Over the course of a case, initial deference can also shift to resentment. Disagreements over strategy (or fees) can form deeper antagonisms, especially once trust is lost. While lawyers expect that a minority of clients will renege on fees, refusal to pay can still be infuriating and hurtful. Getting cheated after a five-year lawsuit led one lawyer to conclude that lawyers and clients "don't completely trust each other" (2007-91).

Certainly in major cases, the intense pressure of environmental lawsuits cannot help but exacerbate tension between lawyers and plaintiffs. Litigation demands stamina, but anxious plaintiffs often want results. Although lawyers usually warn potential clients of the difficulties ahead, many still worry about disappointing them. "I'm embarrassed," one lawyer told me, "because their hopes are on me and I can't get any money for them" (2007-54). Nor are successful clients necessarily grateful. "After hearing the verdict," another lawyer said, "I was so happy

54 Stephen Ellmann, "Lawyers and clients," UCLA Law Review, Vol. 34 (1986-1987), p. 719.

55 This was a reasonable possibility as the client's traveling companion, another potential plaintiff, had been taken into custody the previous night. The client was not arrested, however, but had got lost between the law office and the restaurant. 
that we had won. However, my clients were unhappy that they had not been awarded as much compensation as they had hoped for. Had I lost, they would have blamed it on corrupt court officials, but now that we had won, they blamed it on me."56

\section{Conclusion}

Looking up at environmental law from below, from the point of view of those who bring and fight claims every day, is one way to take stock of how the past 30 years of legal reforms are playing out in contemporary courts. What emerges is a story of tremendous variation. Even in just one type of case, civil environmental litigation, it is hard to sum up how well the courts work. On the one hand, plaintiffs and lawyers agree that environmental cases are difficult and wringing concessions out of polluters requires remarkable persistence. As one of China's most prominent environmental lawyers sums up, “it's incredibly hard to win environmental lawsuits ... litigation is hard; post-litigation enforcement is also hard." 57 On the other hand, these cases, however challenging, are not a lost cause. Sometimes, the process creaks forward such that appraisals are conducted on time, allies solicited and compensation won.

Conceptually, this suggests that the one of the best ways to describe Chinese courts is as uneven. As a new generation of socio-legal research is just starting to explore, ${ }^{58}$ how courts work (and how well they work) depends a great deal on both issue area and local circumstances. Much more remains to be done to answer questions like why environmental cases cluster in certain areas, or why some environmental lawsuits are more successful than others. Future research unravelling these kinds of patterns, or comparing environmental litigation to other types of cases, will help anchor big picture discussions about Chinese legal reforms in concrete insights about the inner workings of a far-flung legal system. Indeed, disaggregating expansive concepts like rule of law into more manageable constituent pieces helps us move away from grand summations to explore complexity and variation instead of glossing over it.

Despite occasional successes, civil environmental litigation remains a weak tool for environmental protection. Above all, near exclusive reliance on post-hoc monetary compensation, rather than preventing harm or restoring the natural environment, indicate that lawsuits are better as a fire alarm for extreme abuses

56 Quoted in Benjamin Van Rooij, "The people vs pollution: understanding citizen action against pollution in China," The Journal of Contemporary China, Vol. 19, No. 63 (2010), p. 71.

57 Quoted in Lin Sha, "Jishiyu: Wang Canfa" ("A timely rain: Wang Canfa), Zhongguo qingnian bao (China Youth Daily), 10 September 2003, available at http://tinyurl.com/6admatb.

58 For example, see Jiahui Ai, "Shehui bianqian zhong de fayuan renshi guanli" ("Managing court personnel amid social transition"), PhD dissertation, Beijing University Law School, 2008; Rongjie Lan, "Susong guize difanghua shizheng yanjiu" ("Empirical research on the localization of litigation rules"), Zhengzhi yu shehui fazhan (Law and Social Development), Vol. 14, No. 2 (2008), pp. 13-22, and Xin He, "Routinization of divorce law practice in China: institutional constraints' influence on judicial behavior," International Journal of Law, Policy and Family, Vol. 23 (2009), pp. 83-109. 
than the potential centrepiece of a serious bid to improve environmental quality. Yet environmental law in China is changing rapidly and new initiatives, like the 2008 Open Environment Regulations and the proliferation of local environmental courts in the mid-to-late 2000 s, may ease litigation by offering a sympathetic venue or improving access to information. Looking forwards, the decision about whether to be optimistic or pessimistic reflects prior expectations as much as anything else. Those expecting an inflexible communist court system uniformly bent on bending the law to protect polluters will be pleasantly surprised, while those searching for litigation-inspired environmentalism will be disappointed.

\section{Appendix: Personal Communications Cited}

\section{6}

2006-3

2006-10

2006-13

2006-15

2006-19

2007

2007-8

2007-9

2007-14

2007-15

2007-18

2007-19

2007-20

2007-21

2007-22

2007-23

2007-27

2007-32

2007-34

2007-35

2007-38

2007-39

$2007-40$
Chinese lawyer, New York City, 28 September

Chinese lawyer, Beijing, 30 November

Staff members from an American NGO, Beijing, 7 December

Chinese environmental NGO staff member, Beijing,

15 December

State Environmental Protection Agency employee, Beijing,

21 December

Chinese lawyer, Beijing, 25 January

Chinese lawyer, Beijing, 26 January

Chinese lawyer, Fujian province, 7 February

Chinese lawyer, Fujian province, 10-11 February

Chinese lawyer, Beijing, 2 March

American NGO representative, Beijing, 4 March

Chinese plaintiff in an environmental lawsuit, Beijing, 5 March

Chinese lawyer, Hebei province, 6 March

Chinese lawyers, plaintiff in an environmental lawsuit, Beijing, 8 March

Chinese lawyer, Beijing, 14 March

Chinese lawyer, Jiangsu province, 20 March

Chinese plaintiffs in an environmental lawsuit, Hebei province, 28 March

Chinese lawyer, Zhejiang province, 5 April

Chinese plaintiff in an environmental lawsuit, Beijing, 10 April

Chinese environmental journalist, Beijing, 19 April

Chinese plaintiff in an environmental lawsuit (Fujian), Beijing, 21 April

Chinese environmental journalist, Beijing, 21 April 


\section{Appendix: Continued}

$\begin{array}{ll}2007-41 & \text { Chinese lawyer, Beijing, 23 April } \\ 2007-46 & \text { Complainants in an environmental dispute, Shanghai, 4 May } \\ 2007-50 & \text { Chinese environmental NGO representative, Beijing, 12 May } \\ 2007-53 & \text { Chinese lawyer, Shanghai, 24 May } \\ 2007-54 & \text { Chinese lawyer, Shanghai, 24 May } \\ 2007-55 & \text { Chinese judge, Shanghai, 25 May } \\ 2007-57 & \text { Chinese lawyer, Zhejiang province, 29 May } \\ 2007-71 & \text { Chinese lawyer, Beijing, 21 August } \\ 2007-73 & \text { Chinese lawyers, Beijing, 28 August } \\ 2007-74 & \text { Chinese judge, Hebei province, 28 August } \\ 2007-75 & \text { Chinese environmental journalist, Beijing, 30 August } \\ 2007-77 & \text { Chinese lawyer, Hubei, 4-5 September } \\ 2007-78 & \text { Chinese lawyer, Hubei, 5 September } \\ 2007-79 & \text { Chinese lawyer, Hubei, 6 September } \\ 2007-82 & \text { Meeting between Chinese lawyers and plaintiffs, Hubei, } \\ & \text { 11 September } \\ 2007-84 & \text { Chinese judge, Beijing, 18 September } \\ 2007-85 & \text { Chinese judge, Beijing, 20 September } \\ 2007-87 & \text { Chinese lawyer, Shanghai, 25 September } \\ 2007-91 & \text { Chinese lawyer, Beijing, 13 October } \\ 2007-94 & \text { Chinese lawyer, Guangdong province, 22 October } \\ 2007-96 & \text { Chinese lawyers, Beijing, 25 October } \\ 2007-97 & \text { Chinese lawyer, Beijing, 25 October } \\ 2007-102 & \text { Chinese lawyer, Zhejiang province, 5 November } \\ 2007-106 & \text { Chinese lawyer, Beijing, 15 November } \\ 2007-107 & \text { Meeting of environmental lawyers, Guangxi province, } \\ 2007-111 & \text { 17 November } \\ 2007-115 & \text { Chinese lawyer, Yunnan province, 29 November } \\ 2008 & \text { Lawyer roundtable, Heilongjiang province, 7 December } \\ 2008-2 & \text { Chinese lawyers, Hubei province, 10 January } \\ 2009 & \\ 2009-5 & \text { Chinese lawyer, Beijing, 20 January } \\ & \\ & \end{array}$

